\title{
EFFECT OF L-TYROSINE ON GROWTH PERFORMANCE AND SOME BLOOD CONSTITUENTS OF SUCKLING FRIESIAN CALVES DURING WINTER AND SUMMER SEASONS
}

\author{
M. A. Abu El-Hamd ${ }^{1}$, M.S. Sayah ${ }^{1}$, Sh. M. Shamiah ${ }^{1}$ and Sh. A. Gabr ${ }^{2}$ \\ 1- Animal Production Research Institute, Agricultural Research Center, Dokki, Egypt, 2- \\ Department of Animal Production, Faculty of Agriculture, Tanta University, Egypt
}

\section{SUMMARY}

Thirty two newly born Friesian calves during winter season, 16 male with average body weight (BW) of $30.69 \mathrm{~kg}$ and 16 female with $B W$ of $30.94 \mathrm{~kg}$ and twenty nine newly born Friesian calves during summer season, 14 male with $B W$ of $30.43 \mathrm{~kg}$ and 15 female with $B W$ of $29.40 \mathrm{~kg}$ were divided into three similar groups. The first group (G1) was served as a control, while the second group (G2) was received orally a dose of $0.1 \mathrm{~g}$ L-tyrosine $\mathrm{kg} \mathrm{BW}$ at the first week and the third group (G3) was received orally with two dose of $0.1 \mathrm{~g}$ L-tyrosine $/ \mathrm{kg} B W$ at the first and eight weeks of age. Results revealed that total dry matter (DM) intake tended to increase during winter compared to summer season. The red blood cells (RBC) count and plasma glucose and creatinine concentrations were higher $(P<0.05)$, however, PCV value was lower $(P<0.05)$ for both $G 2$ and G3 compared to G1. Concentrations of plasma protein $(T P)$, globulin $(G L)$ and cholesterol $(C H D)$ were higher $(P<0.05)$ for both $G 1$ and $G 3$ than that for G2. Count of white blood cells (WBC), hemoglobin $(H B)$ concentration and plasma albumin $(A L)$ and urea (UR) concentrations were nearly similar for the three studied groups. The blood RBC count, HB concentration, PCV value and plasma glucose concentration were higher $(P<0.05)$, however plasma UR and creatinine concentrations were lower $(P<0.05)$ for winter than summer season. Only, WBC and PCV values were lower $(P<0.05)$ for female than male calves. $B W$ at 5, 10 weeks and weaning and average daily gain (ADG) from birth to 5, 6 to 10, 11 week to weaning and during the whole suckling period from birth to weaning were higher $(P<0.05)$ forG 2 and G3 compared with G1. Treatment of G2 and G3 improved weaning weight by 9.66 and $13.11 \mathrm{~kg}$ or 10.49 and $14.23 \%$ compared to G1, respectively. Moreover, ADG during the whole suckling period from birth to weaning increased by 15.25 and 20.34\% for G2 and G3 compared withG1, respectively. $A D G$ during the period from 11 week to weaning was higher $(P<0.05)$ for winter than summer season. $B W$ at 10 week and weaning and $A D G$ from 6 to 10 weeks were higher $(P<0.05)$ for male than female calves. The amounts of whole milk, starter, fresh berseem, berseem hay and total DM required per $\mathrm{kg}$ gain were lower $(P<0.05)$ for $G 2$ and $G 3$ compared withG1. The feed cost per $\mathrm{kg}$ gain was lower $(P<0.05)$, however, the price of daily gain and economic efficiency were higher $(P<0.05)$ forG2 and G3 compared toG1.

\section{Keywords: Friesian calves, L-tyrosine, growth performance, blood constituents}

\section{INTRODUCTION}

Large practical importance for the discrimination between plant and animal proteins, for the identification of corresponding adulterations and the proof of illegal addition of animal derived feedstuffs to cattle feed. The suitable sample material could be milk and meat, but also, for non-invasive and retrospective controls, hair, foot, horn and collagen (Fronza et al., 2002). Plant proteins generally contain quite low amounts of Ltyrosine (Leuthardt, 1963), while those from animal sources can have higher concentrations. This amino acid is not essential for animals, because they are capable to synthesis it from the essential amino acid L-phenylalanine through hydroxylation by phenylalaninehydroxylase.
L-Tyrosine in animal proteins must therefore partially originate from diet and from self-production. Tracer experiments on man showed that the rate of intrinsic phenylalanine hydroxylation is reverse to the tyrosine offered in diet (Thorpe et al., 2000).

Tyrosine is incorporated into all proteins and is a precursor of thyroxin, melanin, and the neurotransmitters dopamine and nor epinephrine (Scriver et al., 1995). L-tyrosine is a conditionally essential amino acid because under normal conditions the body synthesizes sufficient quantities from phenylalanine. For those with phenyl ketonuria, however, a severe deficiency in the enzyme phenylalanine hydroxylase prevents conversion of phenylalanine to tyrosine, making tyrosine an essential amino acid for this population (Van Spronsen et al., 2001). 
Use of organic substances is believed having positive effect on animal productivity (Gabr, 2009). One of these substances is Ltyrosine, which involves in the catecholamine and thyroxin formation (Hammerl and Russe, 1987). Gabr (2009) reported that L-tyrosine increased final body weight, total and daily weight gain of New Zealand rabbits.

The current study was undertaken to examine the effects of L-tyrosine on body weight gain, blood parameters, feed and economic efficiency of suckling Friesian calves during the first week to weaning of age in different seasons.

\section{MATERIALS AND METHODS}

The current work was carried out at Sakha Animal Production Research Station, Animal Production Research Institute, Agricultural Research Center. A total of 32 newly born Friesian calves during winter season, 16 males with an average body weight (BW) of $30.69 \mathrm{~kg}$ and 16 females with BW of $30.94 \mathrm{~kg}$ and 29 newly born Friesian calves during summer season, 14 males with $\mathrm{BW}$ of $30.43 \mathrm{~kg}$ and 15 females with BW of $29.40 \mathrm{~kg}$ were divided into three similar groups. The first group (G1, $\mathrm{n}=21$ ) was served as a control, while the second group $(\mathrm{G} 2, \mathrm{n}=21)$ was received orally a dose of $0.1 \mathrm{~g}$ L-tyrosine / $\mathrm{kg} \mathrm{BW}$ at the first week. The third group $(\mathrm{G} 3, \mathrm{n}=19)$ was received orally two doses of $0.1 \mathrm{~g}$ Ltyrosine $/ \mathrm{kg} \mathrm{BW}$ at the first and eight weeks of age. Calves were removed away from their dams after three days and fed a basal diet consisted of whole milk, starter and fresh berseem (winter season) or berseem hay (summer season).

Calves were artificially fed whole milk in plastic bucket twice daily at 7 a.m. and 5 p.m. during winter and at 7 a.m and 7 p.m. during summer. From the beginning of third week, calves were given the starter once daily at 9 a.m. and fresh berseem or berseem hay at 11 a.m. Water was made available all the day round. Calves were fed according to the recommended requirements of Animal Production Research Institute (1997) as shown in Table (1). Chemical composition of feedstuffs during winter and summer seasons is presented in Table (2).

Blood samples $(5 \mathrm{ml})$ were collected randomly from three males and three females in each group at morning from jugular vein using heparinized vacutainer tubes. Blood was collected before feeding and drinking biweekly. Blood samples were centrifuged at $4000 \mathrm{rpm}$ for 15 minutes. Blood plasma were carefully separated and stored at $-20{ }^{\circ} \mathrm{C}$ until analysis.
Hematological parameters including count of red blood cells (RBCs). white blood cells (WBCs), packed cell volume (PCV\%), and hemoglobin concentration were counted or measured in fresh whole blood using fully digital haematology counter (Laboratories, USA).

Concentration of total proteins, albumin, urea-N, creatinine and glucose in blood plasma were determined using commercial kits (Diagnostic System Laboratories, Inc., USA). Plasma globulin was calculated by subtracting concentration of albumin from total proteins.

Feed conversion efficiency was calculated as the amounts of whole milk, starter, fresh berseem, berseem hay and total DM required/ $\mathrm{kg} \mathrm{BW}$ gain. Economic efficiency expressed as average daily feed cost, feed cost/ $\mathrm{kg}$ gain, the price of average daily gain (ADG) and economic efficiency as the ratio between the price of ADG and average daily feed cost were calculated according to the prices of 2011.

The obtained data were statistically analyzed using general linear models factorial design using SPSS (2008). The significant differences among treatment groups were tested using Duncan's Multiple Range Test (Duncan, 1955).

\section{RESULTS AND DISCUSSION}

Average daily intakes of different feedstuffs were similar in the three studied groups (Table 1). DM intake tended to increase during winter compared to summer, nearly the same for male and female calves. Daily rhythms in the metabolism of dietary amino acids led to the discovery of a relationship between nutrient intake and neurotransmission (Wurtman et al., 1981).

The red blood cells (RBC) count and plasma glucose and creatinine concentrations were higher $(\mathrm{P}<0.05)$, however $\mathrm{PCV}$ value was lower $(\mathrm{P}<0.05)$ in $\mathrm{G} 2$ and $\mathrm{G} 3$ compared to $\mathrm{G} 1$ (Table 3). Plasma total protein (TP), globulin (GL) and cholesterol (CHD) were higher $(\mathrm{P}<0.05)$ in $\mathrm{G} 1$ and G3 than G2 (Table 4). The white blood cells (WBC) count, hemoglobin (HB) concentration and plasma albumin (AL) and urea (UR) concentrations were nearly similar for the studied groups (Table 4).

The blood RBC count, HB concentration, PCV value and plasma glucose concentration were higher $(\mathrm{P}<0.05)$, however plasma UR and creatinine concentrations were lower $(\mathrm{P}<0.05)$ for winter than summer (Table 4). While, blood WBC count and plasma TP, AL, GL and CHD concentrations were nearly similar for winter and summer. Only, WBC and PCV values were lower $(\mathrm{P}<0.05)$ for female than male calves, while the other blood constituents 
were nearly similar for both male and female calves.

BW and ADG of suckling Friesian calves are shown in Table (5) and Figures. (1-3). BW at 5, 10 weeks and weaning and ADG from birth to 5 weeks, 6 to 10 weeks, 11 week to weaning and during the whole suckling period from birth to weaning were higher $(\mathrm{P}<0.05)$ for G2 and G3 compared with G1. While, no significant differences $(\mathrm{P}>0.05)$ was observed between G2 or G3. Treatments of G2 and G3 The one and two doses orally L-tyrosine improved weaning weight by 9.66 and 13.11 $\mathrm{kg}$ or 10.49 and $14.23 \%$ compared to G1, respectively. Moreover, ADG during the whole suckling period increased by 0.09 and $0.12 \mathrm{~kg}$ or 15.25 and $20.34 \%$ for G2 and G3 compared with $\mathrm{G} 1$, respectively. $\mathrm{BW}$ and $\mathrm{ADG}$ were nearly similar for winter and summer seasons except ADG during the period from 11 week to weaning, which was higher $(\mathrm{P}<0.05)$ for winter than summer. Moreover, BW at 10 week and weaning and ADG at the period from 6 to 10 weeks were higher $(\mathrm{P}<0.05)$ for male than female calves. One of these substances is Ltyrosine, which involves in the catecholamine and thyroxin formation (Hammerl and Russe, 1987). Gabr (2009) reported that L-tyrosine increased BW, total gain and ADG of New Zealand rabbits.

Growth performance may have been stimulated by the effect of tyrosine on hormonal regulation. The availability of tyrosine in relation to phenylalanine and the other large, neutral amino acids (tryptophan, valine, leucine, and isoleucine) appears to regulate brain catecholamine synthesis in rats (Wurtman, 1982). Administration of tyrosine to rats resulted in increased energy intakes (Anderson, 1979) and alterations of blood flow (Martin, 1980) by catecholamine mediated mechanisms. In dairy cows, a small increased is energy intake could stimulate growth performance. Brain catecholamines, particularly nor epinephrine, also are believed to be potent stimulators of growth hormone release (Martin, 1980).

Tyrosine supplement may have stimulated microbial activity because of the additional nitrogen. Fifty grams of tyrosine contains $7.7 \mathrm{~g}$ nitrogen. The basal diet already provided $670 \mathrm{~g}$ nitrogen/cow /day, tyrosine supplementation is unlikely to have stimulated microbial growth because of the additional N (Rae and Ingalls, 1984).

Economic evaluation expressed as daily feed cost, feed cost per $\mathrm{kg}$ gain, price of daily gain and economic efficiency as the ratio between price of daily gain and daily feed cost are presented in Table (7). The daily feed cost for $\mathrm{G} 3$ was higher $(\mathrm{P}<0.05)$ than that of $\mathrm{G} 1$.
While, G2 had no significant difference with G1 and G3. The feed cost / kg gain was lower $(\mathrm{P}<0.05)$, and the price of daily gain and economic efficiency were higher $(\mathrm{P}<0.05)$ for G2 and G3 compared to G1. While there were not significant differences between G2 and G3. Moreover, there were not significant differences $(\mathrm{P}>0.05)$ in daily feed cost, feed cost / kg gain, price of daily gain and economic efficiency between winter and summer as well as between male and female calves.

Data in Table (6) revealed that oral Ltyrosine to suckling Friesian calves improved feed conversion efficiency. The amounts of whole milk, starter, fresh berseem, berseem hay and total $\mathrm{DM}$ required / $\mathrm{kg}$ gain were lower $(\mathrm{P}<0.05) \mathrm{G} 2$ and $\mathrm{G} 3$ compared with $\mathrm{G} 1$. While, there no significant differences $(\mathrm{P}>0.05)$ between G2 and G3. These differences in feed conversion attributed to the differences in ADG as shown in Table (5). Moreover, there were no significant differences $(\mathrm{P}<0.05)$ in feed conversion between winter and summer seasons as well as between male and female calves.

\section{CONCLUSION}

The present study indicated the beneficial effects of L-tyrosine treatment $0.1 \mathrm{~g} / \mathrm{kg} \mathrm{BW}$ weight on first and eight week of age were on productive performance of suckling Friesian calves during suckling period and improvement of feeding values and economic efficiency

\section{REFERENCES}

Anderson, G.H., 1979. Control of protein and energy intake: role of plasma amino acids and brain neurotransmitters. Can. J. Physiol. Pharmacol. 57:1043.

Animal Production Research Institute, 1997. Animal Nutrition Scientifically and Practically. 1st Ed. Animal Production Research Institute, Agricultural Research Center, Ministry of Agriculture, Dokki, Giza, Egypt.

Duncan, D.B., 1955. Multiple rang and multiple F test. Biometrics 11: 1-42.

Fronza, G., C. Fuganti, H.L. Schmidt and R.A. Werner, 2002. The $\delta^{18} \mathrm{O}$-value of the $p$-OH group of L-tyrosine permits the assignment of its origin to plant or animal sources. Eur. Food Res. Technol., 215: 55-58.

Gabr, Sh.A., 2009. The relay of sexual puberty in rabbit male by L-tyrosine or carnitine treatment. J. Agric. Res. Kafrelsheikh Univ., 35 (1) 56-68.

Martin, J.B., 1980. Functions of central nervous system neurotransmitters in 
regulation of growth hormone secretion. Fed. Proc. 39:2902.

Rae R.C. and J.R. Ingalls, 1984. Lactational response of dairy cows to oral administration of L-tyrosine J. Dairy Sci., 67:1430-1438.

Scriver, C.R., S. Kaufman and S.L.C. Woo, 1995. The hyperphenylalaninemias. In: Scriver CR, Beaudet AL, Sly WS, Valle D, eds. The metabolic basis of inherited disease. 7th ed. New York: McGrawHill,:1015-75.

SPSS, 2008. Statistical package for the social sciences, Release: 16, SPSS INC, Chicago, USA
Thorpe, J.M., S.A. Roberts, R.O. Ball and P.B. Pencharz, 2000. Metabolism, 49: 444-449.

Van Spronsen, F.J., M. van Rijn, J. Bekhof, R. Koch and P.G.A. Smit, 2001. Phenylketonuria: tyrosine supplementation in phenylalanine-restricted diets. Am. J. Clin. Nutr., 73: 153-157.

Wurtman, R.J., 1982. Nutrients that modify brain function. Sci. Am. 246 (4):50.

Wurtman, R.J., F. Hefti, and E. Melamed 1981. Precursor control of neurotransmitter synthesis. Pharmacol. Rev. 32:315-335.

Table 1. Daily requirements of feedstuffs intake $(\mathrm{kg} / \mathrm{head})$ during suckling period

\begin{tabular}{lcccccccc}
\hline \multirow{2}{*}{ Feedstuff: } & \multicolumn{8}{c}{ Age (week) } \\
\cline { 2 - 8 } & $\mathbf{1 - 2}$ & $\mathbf{3 - 4}$ & $\mathbf{5 - 6}$ & $\mathbf{7 - 8}$ & $\mathbf{9 - 1 0}$ & $\mathbf{1 1 - 1 2}$ & $\mathbf{1 3 - 1 4}$ & $\mathbf{1 5}$ \\
\hline Whole milk & $3.5-4$ & $4.5-5$ & $5-4.5$ & $4-3.5$ & $3-2.5$ & $2-1.75$ & $1.5-1.25$ & 1 \\
Starter** & - & 0.25 & 0.50 & 0.75 & 1.00 & 1.25 & 1.50 & 1.75 \\
Fresh berseem & - & 1 & 1.5 & 2 & 2.5 & 3 & 3.5 & 4 \\
Berseem hay & - & 0.1 & 0.2 & 0.3 & 0.4 & 0.5 & 0.6 & 0.7 \\
\hline
\end{tabular}

$*$ as fed.

** Starter consisted of $15 \%$ soybean meal, $10 \%$ linseed cake, $34 \%$ ground yellow corn grain, $20 \%$ wheat bran,

$15 \%$ rice bran, $3 \%$ molasses, $2 \%$ limestone and $1 \%$ common salt.

Table 2. Chemical composition of feedstuffs for winter and summer seasons

\begin{tabular}{lccccccc}
\hline \multirow{2}{*}{ Item } & \multirow{2}{*}{ DM \% } & \multicolumn{7}{c}{ Composition of DM \% } \\
\cline { 3 - 8 } & & OM & CP & CF & EE & NFE & Ash \\
\hline Winter season & 12.45 & 94.60 & 25.72 & - & 30.36 & 38.52 & 5.40 \\
Whole milk & 91.15 & 92.34 & 18.23 & 5.87 & 3.48 & 64.76 & 7.66 \\
Starter & 16.61 & 89.15 & 16.26 & 24.45 & 2.87 & 45.57 & 10.85 \\
Fresh berseem & & & & & & & \\
Summer season & 11.84 & 93.76 & 24.18 & - & 29.54 & 40.04 & 6.24 \\
Whole milk & 91.42 & 92.16 & 18.21 & 5.92 & 3.43 & 64.60 & 7.84 \\
Starter & 90.65 & 90.46 & 13.37 & 28.15 & 2.64 & 46.30 & 9.54 \\
Berseem hay & & & & & & & \\
\hline
\end{tabular}

Table 3. Effect of treatments on average daily feed intake (kg/head)

\begin{tabular}{lccccc}
\hline \multicolumn{1}{c}{ Item } & Whole milk & Starter & $\begin{array}{c}\text { Fresh } \\
\text { berseem }\end{array}$ & Berseem hay & Total DM \\
\hline Treatments & 3.03 & 0.82 & 1.08 & 0.16 & 1.44 \\
Control & 3.03 & 0.82 & 1.08 & 0.16 & 1.44 \\
One dose & 3.03 & 0.82 & 1.08 & 0.16 & 1.44 \\
Two dose & & & & & \\
Season & 3.03 & 0.82 & 2.07 & - & 1.47 \\
Winter & 3.03 & 0.82 & - & 0.33 & 1.40 \\
Summer & 3.03 & 0.82 & 1.10 & 0.15 & 1.44 \\
Sex & 3.03 & 0.82 & 1.07 & 0.16 & 1.43 \\
Male & & & & & \\
Female & & &
\end{tabular}


Table 4. Effect of treatments on blood hematology and blood plasma constituents

\begin{tabular}{lcccccccccc}
\hline \multirow{2}{*}{ Items } & \multicolumn{4}{c}{ Treatments } & \multicolumn{4}{c}{ Season } & \multicolumn{4}{c}{ Sex } \\
\cline { 2 - 11 } RBC & G1 & G2 & G3 & MSE & Winter & Summer & MSE & Male & Female & MSE \\
WBC & $8.41^{\mathrm{b}}$ & $9.31^{\mathrm{a}}$ & $8.98^{\mathrm{a}}$ & 0.27 & $9.30^{\mathrm{a}}$ & $8.53^{\mathrm{b}}$ & 0.24 & 8.90 & 8.93 & 0.25 \\
HB & 12.05 & 11.95 & 11.76 & 0.24 & 12.11 & 11.72 & 0.27 & $11.58^{\mathrm{b}}$ & $12.25^{\mathrm{a}}$ & 0.19 \\
PCV & 8.73 & 8.75 & 9.05 & 0.33 & $9.35^{\mathrm{a}}$ & $8.34^{\mathrm{b}}$ & 0.28 & 9.03 & 8.67 & 0.31 \\
TP & $35.03^{\mathrm{a}}$ & $33.64^{\mathrm{b}}$ & $33.62^{\mathrm{b}}$ & 0.29 & $35.44^{\mathrm{a}}$ & $32.70^{\mathrm{b}}$ & 0.75 & $33.62^{\mathrm{b}}$ & $34.53^{\mathrm{a}}$ & 0.22 \\
AL & $8.03^{\mathrm{a}}$ & $7.51^{\mathrm{b}}$ & $7.90^{\mathrm{a}}$ & 0.11 & 7.92 & 7.69 & 0.13 & 7.75 & 7.87 & 0.12 \\
GL & 3.90 & 3.69 & 3.76 & 0.10 & 3.80 & 3.76 & 0.11 & 3.73 & 3.83 & 0.10 \\
UR & $4.13^{\mathrm{a}}$ & $3.82^{\mathrm{b}}$ & $4.13^{\mathrm{a}}$ & 0.08 & 4.12 & 3.94 & 0.09 & 4.02 & 4.04 & 0.10 \\
CHD & 31.41 & 28.64 & 30.55 & 2.03 & $26.93^{\mathrm{b}}$ & $33.44^{\mathrm{a}}$ & 1.95 & 30.92 & 29.46 & 2.1 \\
Glucose & $200.77^{\mathrm{a}}$ & $187.66^{\mathrm{b}}$ & $201.23^{\mathrm{a}}$ & 3.54 & 195.99 & 197.13 & 3.78 & 197.46 & 195.65 & 3.24 \\
Creatinine & $77.57^{\mathrm{b}}$ & $82.20^{\mathrm{a}}$ & $79.69^{\mathrm{ab}}$ & 1.23 & $83.38^{\mathrm{a}}$ & $76.35^{\mathrm{b}}$ & 1.76 & 80.84 & 78.89 & 1.56 \\
\hline
\end{tabular}

$\mathrm{a}, \mathrm{b}, \mathrm{c}$ : Values in the same row with different superscripts differ significantly $(\mathrm{P}<0.05)$.

$\mathrm{G} 1=$ control, G2= one dose at the first week and G3= two doses of $0.1 \mathrm{~g} \mathrm{~L}$-tyrosine $/ \mathrm{kg} \mathrm{BW}$ at the first and eight weeks of age.

Table 5. Body weight and average daily gain of suckling Friesian calves

\begin{tabular}{|c|c|c|c|c|c|c|c|c|c|}
\hline \multirow[b]{2}{*}{ Item } & \multirow{2}{*}{$\begin{array}{l}\text { No. of } \\
\text { animals }\end{array}$} & \multicolumn{4}{|c|}{ Body weight (kg) } & \multicolumn{4}{|c|}{ Average daily gain (kg) } \\
\hline & & Birth & $\begin{array}{c}5 \\
\text { week } \\
\end{array}$ & $\begin{array}{c}10 \\
\text { week }\end{array}$ & Weaning & $\begin{array}{c}1-5 \\
\text { week }\end{array}$ & $\begin{array}{r}6-10 \\
\text { week }\end{array}$ & $\begin{array}{l}11-15 \\
\text { week }\end{array}$ & $\begin{array}{r}1-15 \\
\text { week }\end{array}$ \\
\hline \multicolumn{10}{|l|}{ Treatments } \\
\hline$\overline{\mathrm{G} 1 \text { (control) }}$ & 21 & 30.57 & $45.00^{\mathrm{b}}$ & $65.29^{\mathrm{b}}$ & $92.10^{\mathrm{b}}$ & $0.41^{\mathrm{b}}$ & $0.58^{\mathrm{b}}$ & $0.77^{\mathrm{b}}$ & $0.59^{b}$ \\
\hline G2 (one dose) & 21 & 29.86 & $48.67^{\mathrm{a}}$ & $72.52^{\mathrm{a}}$ & $101.76^{\mathrm{a}}$ & $0.54^{\mathrm{a}}$ & $0.68^{\mathrm{a}}$ & $0.84^{\mathrm{a}}$ & $0.68^{\mathrm{a}}$ \\
\hline G3 (two doses) & 19 & 30.74 & $49.63^{\mathrm{a}}$ & $74.74^{\mathrm{a}}$ & $105.21^{\mathrm{a}}$ & $0.54^{\mathrm{a}}$ & $0.72^{\mathrm{a}}$ & $0.87^{\mathrm{a}}$ & $0.71^{\mathrm{a}}$ \\
\hline MSE & - & 2.17 & 1.13 & 2.11 & 2.68 & 0.03 & 0.03 & 0.012 & 0.02 \\
\hline \multicolumn{10}{|l|}{ Season } \\
\hline$\overline{\text { Winter }}$ & 32 & 30.81 & 47.81 & 70.69 & 100.41 & 0.49 & 0.65 & $0.85^{\mathrm{a}}$ & 0.66 \\
\hline Summer & 29 & 29.90 & 47.59 & 70.76 & 98.52 & 0.51 & 0.66 & $0.79^{\mathrm{b}}$ & 0.65 \\
\hline MSE & - & 2.21 & 1.21 & 1.04 & 2.11 & 0.03 & 0.04 & 0.015 & 0.03 \\
\hline \multicolumn{10}{|l|}{$\underline{\operatorname{Sex}}$} \\
\hline$\overline{\text { Male }}$ & 30 & 30.57 & 48.23 & $72.37^{\mathrm{a}}$ & $101.60^{\mathrm{a}}$ & 0.50 & $0.69^{\mathrm{a}}$ & 0.84 & 0.68 \\
\hline Female & 31 & 30.19 & 47.19 & $69.13^{\mathrm{b}}$ & $97.48^{\mathrm{b}}$ & 0.49 & $0.63^{b}$ & 0.81 & 0.64 \\
\hline MSE & - & 1.45 & 1.26 & 0.92 & 0.94 & 0.04 & 0.012 & 0.03 & 0.02 \\
\hline
\end{tabular}

$\mathrm{a}, \mathrm{b}$ : Values in the same row with different superscripts differ significantly $(\mathrm{P}<0.05)$.

Table 6. Feed conversion ( $\mathrm{kg} / \mathrm{kg}$ gain) of suckling Friesian calves

\begin{tabular}{lccccc}
\multicolumn{1}{c}{ Item } & Whole milk & Starter & $\begin{array}{c}\text { Fresh } \\
\text { berseem }\end{array}$ & Berseem hay & Total DM \\
\hline Treatments & & & & & \\
\hline G1 (control) & $5.20^{\mathrm{a}}$ & $1.40^{\mathrm{a}}$ & $1.85^{\mathrm{a}}$ & $0.27^{\mathrm{a}}$ & $2.46^{\mathrm{a}}$ \\
G2 (one dose) & $4.45^{\mathrm{b}}$ & $1.20^{\mathrm{b}}$ & $1.53^{\mathrm{b}}$ & $0.24^{\mathrm{b}}$ & $2.10^{\mathrm{b}}$ \\
G3 (two doses) & $4.32^{\mathrm{b}}$ & $1.16^{\mathrm{b}}$ & $1.58^{\mathrm{b}}$ & $0.22^{\mathrm{b}}$ & $2.05^{\mathrm{b}}$ \\
MSE & 0.23 & 0.06 & 0.08 & 0.008 & 0.11 \\
Season & & & & & \\
Winter & 4.64 & 1.25 & 3.16 & - & 2.24 \\
Summer & 4.71 & 1.27 & - & 0.51 & 2.18 \\
MSE & 0.24 & 0.07 & - & - & 0.13 \\
Sex & & & & & 2.16 \\
Male & 4.56 & 1.23 & 1.64 & 0.23 & 2.26 \\
Female & 4.77 & 1.29 & 1.67 & 0.25 & 0.12 \\
MSE & 0.22 & 0.07 & 0.07 & 0.01 & \\
\hline
\end{tabular}

a, b: Values in the same row with different superscripts differ significantly $(\mathrm{P}<0.05)$ 
Table 7. Economic evaluation of suckling Friesian calves

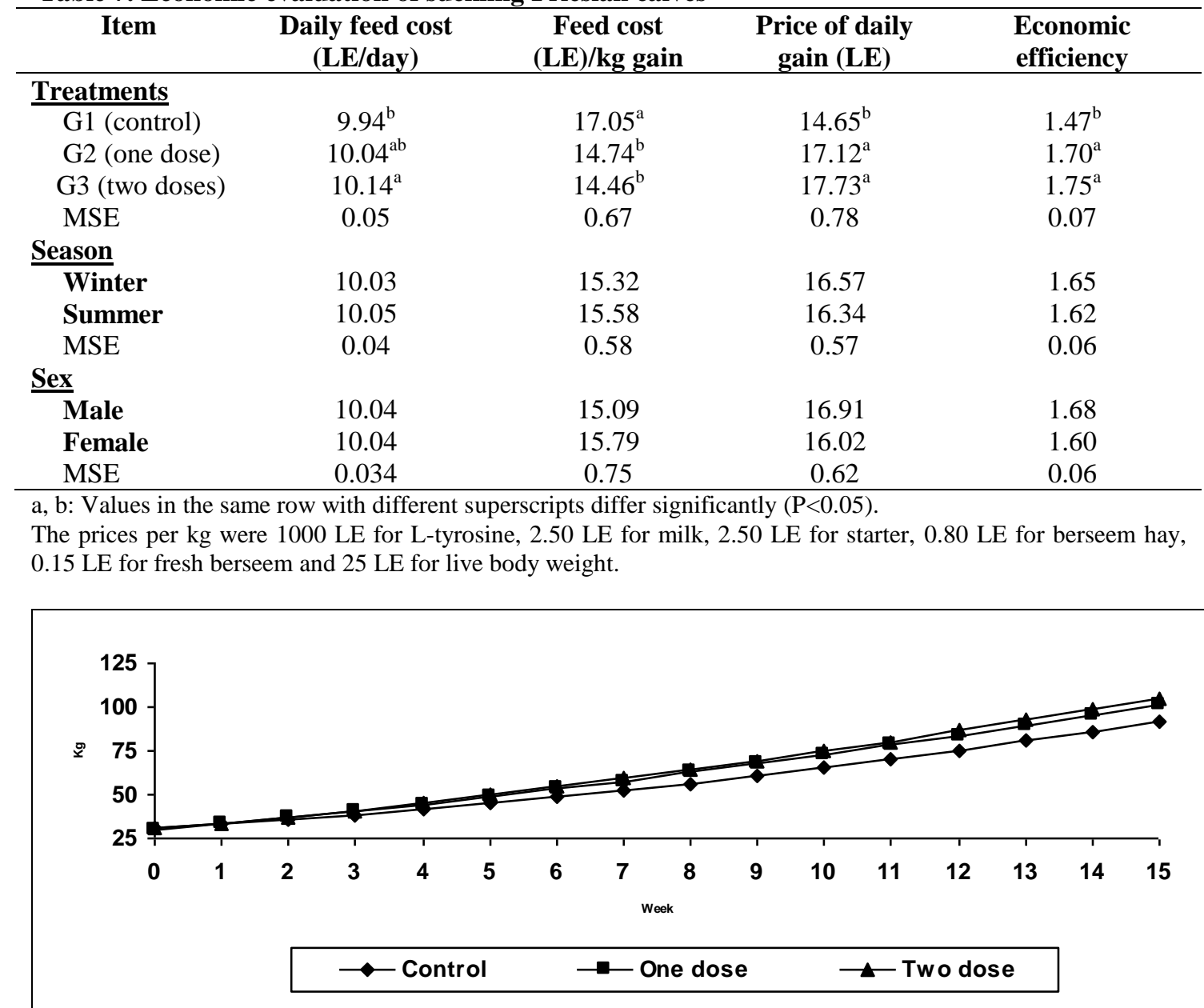

Figure 1. The body weight of suckling Friesian calves in treatments and control group

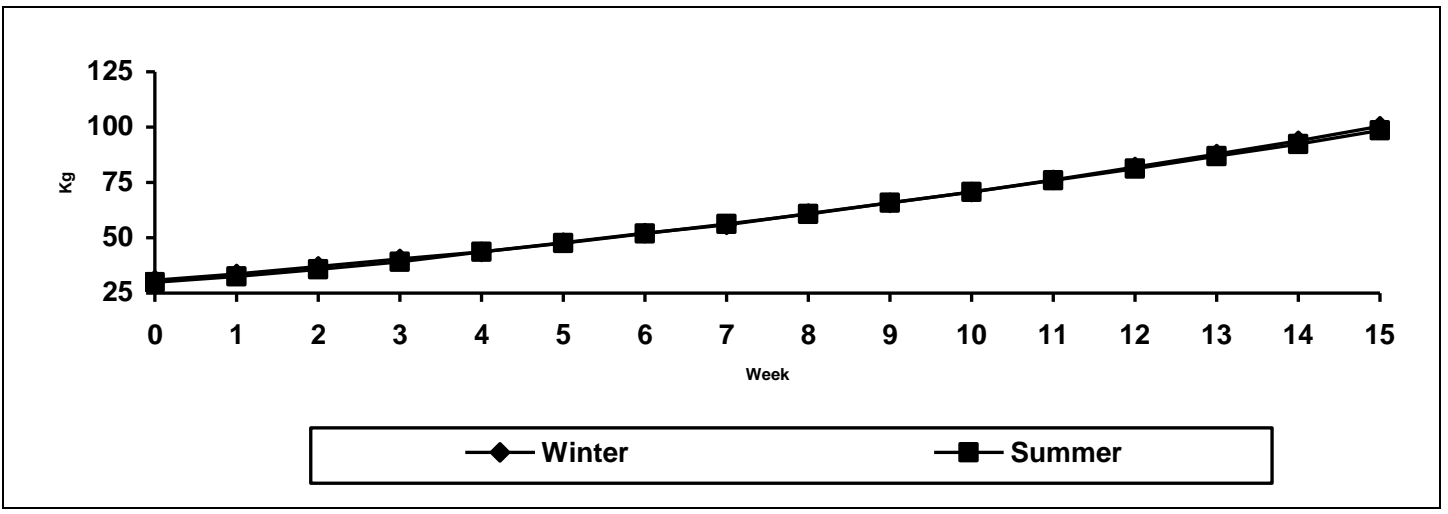

Figure 2. The body weight of suckling Friesian calves during winter and summer 


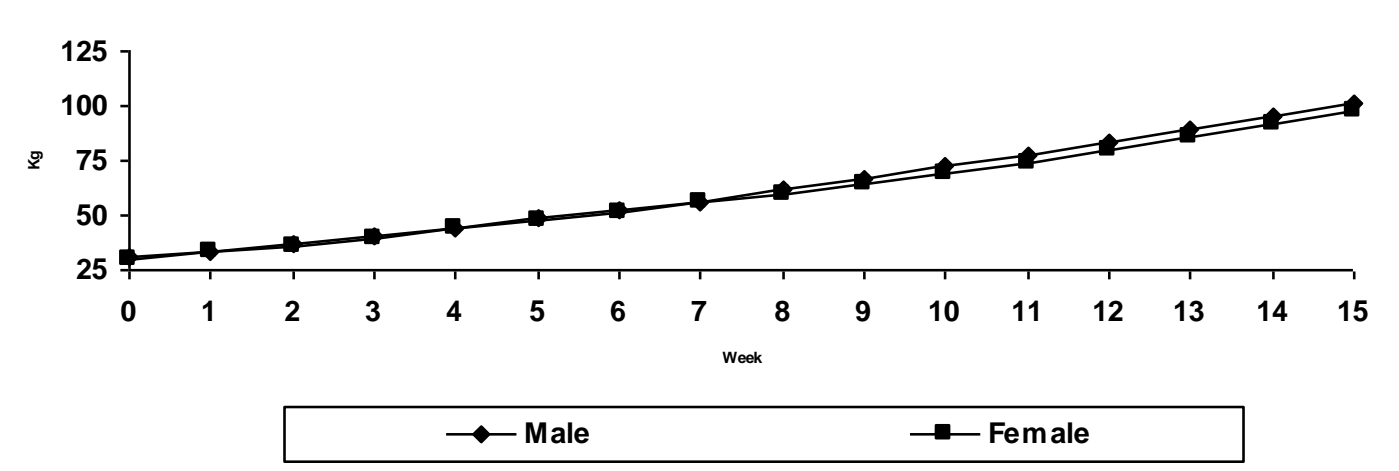

Figure 3. The body weight of male and female suckling Friesian calves

تأثثير التيروسين على خصائص النمو وبعض خصائص اللام للعجول الفريزيـان الرضيعة خلال فصلى الصيف و الشتاء

محمد عوض أبو الحمد1, محمود سيد صياح'، شريف مغاورى شاميه1' وشريف عبد الونيس جبر² معهج بحوث الإنتاج الحيواني، مركز البحوث النزراعية، وزارة الزراعة، دقى، مصر، 2- قسم الإتتاج الحيواني، كليّة الزراعة، جامعة

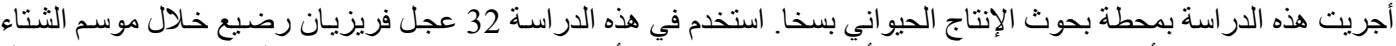

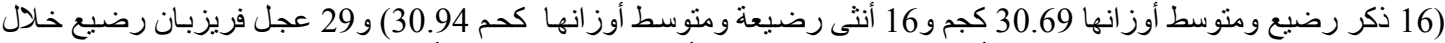

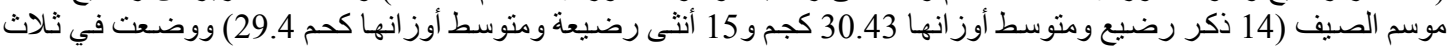

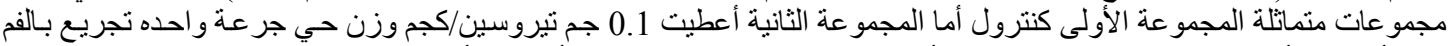

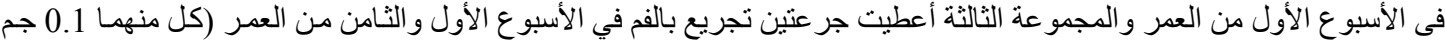

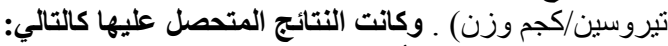

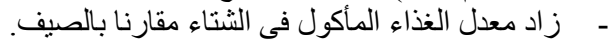

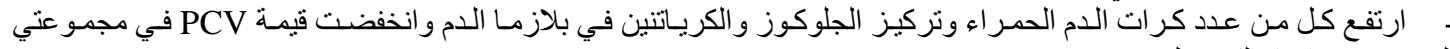

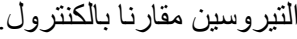

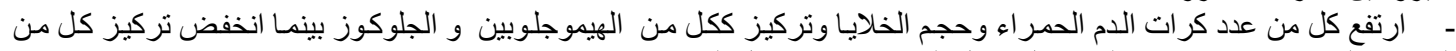

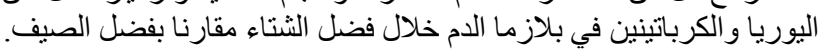

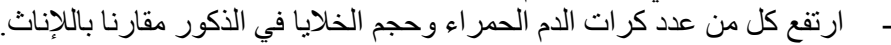

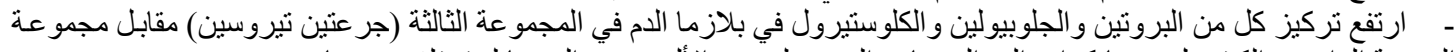

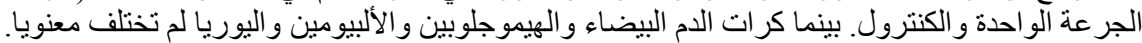

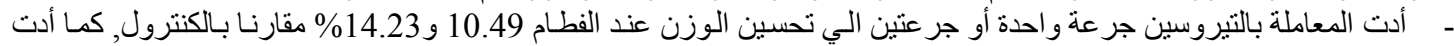

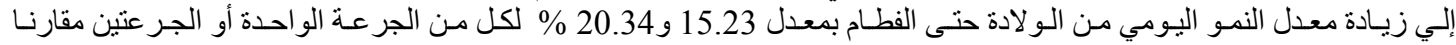

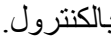
- زاد معدل النمو في الفترة من عمر 11 اسبوع وحتي الفطام زيادة معنوية في فصل الثتاء مقارنا بفصل الصيف.

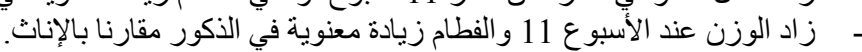
- أظهرت العجول المعاملة بجر عتين من التيروسين اعلي كفاءة اقتصادية عاليه ثم العجول المعاملة بجر عة واحده مقارنا بالكنترول. 